\title{
Implementasi Sensor Inertial Meansurenment Unit (IMU) untuk Monitoring Perilaku Roket
}

\author{
Mudarris*, Satria Gunawan Zain \\ Pendidikan Teknik Elektro, Universitas Negeri Makassar, Makassar \\ * email: mudarrisalfaridzy@gmail.com
}

\begin{abstract}
This paper examines the Implementation of the Inertial Measurement Unit (IMU) Sensor for Monitoring Rocket Attitude. The monitored rocket attitude data is in the form of vibration which is generated by the payload during the functional test and flight speed, acceleration and direction flight test. The rocket payload device is mounted in the rocket compartment for the function of measuring rocket behavior. Data is sent to ground stations via telemetry devices use baud rate of 57600. Based on the results of G-Shock, G-Force and Vibration testing shows that the payload can work well. In accordance with the results of reading the data on the Graphical user Interface (GUI) can be displayed and shows the rocket payload works well. This rocket payload can transmit data remotely.
\end{abstract}

Keywords — Payload, Rocket Attitude, IMU, Monitoring, Rocket

\section{PENDAHULUAN}

Teknologi penerbangan dan antariksa merupakan salah satu teknologi unggulan bagi negara-negara maju, terutama berupa teknologi roket yang di dalamnya termasuk sistem kendalinya dan muatan roket (payload). Penguasaan teknologi roket balistik di Indonesia telah mencapai tingkat yang lebih baik. Penguasaan teknologi roket balistik dapat menunjang dalam penerapannya untuk roket kendali. Roket kendali membutuhkan perangkat roket balistik ditambahkan mekanisme kendali berupa rudder dan elevator. Untuk dapat melakukan kendali yang baik dibutuhkan studi terhadap perilaku roket saat terbang yang mengalami perubahan perlakukan terhadap rudder dan elevator. Untuk mengetahui perilaku saat terbang dibutuhkan sensor yang sesuai. Ada beberapa sensor yang dapat digunakan untuk mengukur perilaku roket. Perilaku roket yang dapat diukur berupa kecepatan, posisi, ketinggian, percepatan, dan sikap roket. Untuk posisi dibutuhkan sensor berupa sensor GPS [1,2]. Percepatan, kecepatan membutuhkan sensor accelero [3] dan ketinggian dapat menggunakan sensor barometer [4]. Sedangkan sikap roket diukur menggunakan sensor gyroscope [3].

Sistem monitoring secara real time pada payload untuk roket uji muatan menjadi hal yang wajib ada dalam mengetahui performa dari roket yang dikembangkan. Sistem ini terdiri dari perangkat sensor dan perangkat telemetri radio. Data sensor dikirimkan dari roket yang sedang terbang melalui media telemetri. Pada ground station, data sensor diamati dalam bentuk grafis dan data array. Sensor yang dipasang pada payload minimal dapat memberikan informasi terkait kecepatan, percepatan, arah dan posisi roket.

Untuk dapat mengukur kecepatan, percepatan serta arah roket dibutuhkan modul sensor IMU yang di dalamnya telah terintegrasi sensor accelero dan gyroscope. Dalam artikel ini akan dibahas dan dianalisis penerapan sensor IMU sebagai perangkat pembaca data kecepatan, percepatan, dan arah dari roket.

Manuscript submitted 18 January 2020; revised 31 January 2020; accepted 2 February 2020. Published 3 February 2020; http://dx.doi.org/10.28989/avitec.v2i1.610 


\section{METODE}

\subsection{Muatan Roket}

Muatan roket (payload) adalah substansi yang dibawa di dalam roket, dapat sebagai payload pengindra dinamik roket itu sendiri atau sebagai misi tertentu, misalnya muatan sensor meteorologi (sonda). Muatan roket berbentuk tabung silinder berisi rangkaian elektronik yang berfungsi sebagai perangkat telemetri untuk trajectory monitoring roket secara visual dalam bentuk grafik 3 dimensi mulai dari peluncuran hingga mendarat ke bumi, secara waktu nyata (realtime tampil di layar GCS ketika sedang meluncur) [5].

Payload merupakan tabung silinder berisi rangkaian elektronik yang berfungsi sebagai perangkat telemetri dengan menggunakan beberapa sensor, pemroses dan pengirim data [4]. Muatan Roket (payload) berbentuk tabung silinder dengan diameter $\pm 10 \mathrm{~cm}$ dengan tinggi maksimal $20 \mathrm{~cm}$ dan berat total maksimal $1 \mathrm{~kg}$. Muatan roket ini berisi rangkaian elektronik, sensor, sistem aktuator robotik, serta kamera yang berfungsi sebagai perangkat telemetri untuk meteorologi sekaligus memiliki sistem aktuator berbasis robotika untuk mengetahui sikap roket saat meluncur serta dapat mengambil gambar dari atas bumi setelah terjadi separasi untuk pemantauan di udara. Muatan roket harus dapat memberikan data secara real time ke ground station hasil dari telemetri serta data gambar. Salah satu contoh payload roket dapat dilihat pada Gambar 1.

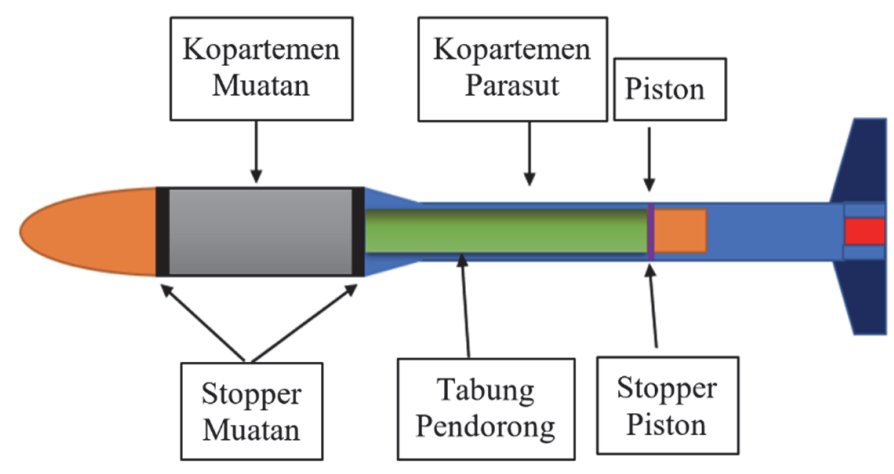

(a) Kompartemen Roket Uji Muatan (RUM)

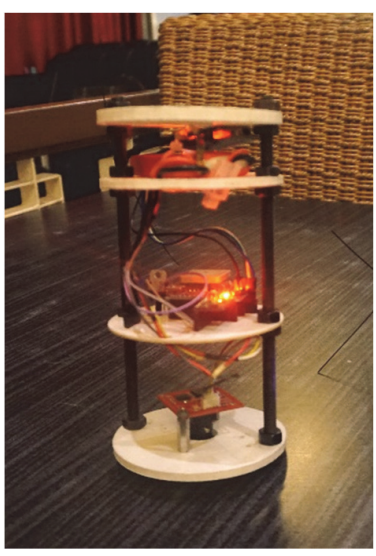

(b) payload

Gambar 1. Payload roket

\subsection{Roket Uji Muatan (RUM)}

RUM (Roket Uji Muatan) adalah jenis roket yang digunakan untuk melakukan pengujian muatan roket sebagai wahana yang membawa muatan roket sesuai misi tertentu [2]. Melalui roket uji muatan tersebut, dapat dilakukan pemantauan jarak jauh sikap luncur wahana melalui layar komputer (laptop) secara grafis waktu nyata (realtime) 3 dimensi yang diperoleh dari data sensor-sensor yang dipasang pada muatan roket. Spesifikasi Teknis Roket Uji Muatan (RUM) dapat dilihat pada Tabel 1. 
Tabel 1. Spesifikasi Roket Uji Muatan (RUM)

\begin{tabular}{l|l}
\hline \multicolumn{1}{c|}{ Parameter } & \multicolumn{1}{c}{ Spesifikasi } \\
\hline Panjang Roket & $1230 \mathrm{~mm}$ \\
\hline Diameter Roket & $76 \mathrm{~mm}$ \\
\hline Berat Roket & $4,6 \mathrm{~kg}$ \\
\hline Jenis Bahan Bakar & Propelan Komposit \\
\hline Daya Dorong & $30 \mathrm{kgf}$ \\
\hline Ketinggian Maksimal & $600 \mathrm{~m}$ \\
\hline Berat Payload & $1 \mathrm{~kg}$ \\
\hline Diameter Payload & $10 \mathrm{~mm}$ \\
\hline Tinggi muatan & $200 \mathrm{~mm}$ \\
\hline Bahan Roket & Pipa PVC \\
\hline
\end{tabular}

\subsection{Inertial Meansurnment Unit (IMU)}

Menurut Riyadi (2009) Inertial Measurement Unit (IMU) merupakan suatu unit dalam modul elektronik yang mengumpulkan data percepatan angular dan akselerasi linear, yang kemudian dikirim ke unit pemroses utama [8]. IMU terdiri dari accelerometer (sensor percepatan) dan gyroscope (sensor angular). Keduanya dapat digunakan untuk menjejaki keberadaan dan pergerakan suatu benda. Accelerometer digunakan untuk mengukur percepatan suatu benda dan gyroscope digunakan untuk mengukur rotasi dari suatu benda. Sebuah penelitian terhadap sistem instrumentasi IMU dapat dilakukan dengan memanfaatkan sensor accelerometer dan sensor gyroscope. Suatu informasi posisi / jarak dapat diperoleh dari keluaran sensor accelerometer melalui proses algoritma tertentu.

Tipe terbaru dari modul IMU adalah 10 DOF IMU Module GY-87 dengan feature Sensor Accelerometer dan Gyroscope (MPU 6050), Sensor Kompas (HMC5883L) dan Barometer (BMP180). Tetapi pada penelitian ini hanya sensor MPU 6050 dan Sensor HMC5883L yang digunakan. Modul IMU 10 DOF (GY-87) dapat dilihat pada gambar 2.

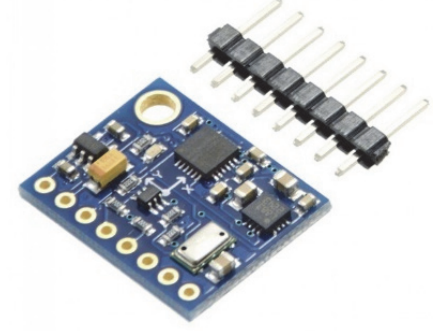

Gambar 2. MU 10 DOF I Module GY-87

Sensor three-axis accelerometer ini digunakan sebagai sensor untuk mendeteksi kemiringan payload terhadap sumbu x (pitch) dan sumbu y (roll) [5]. Untuk mencari sudut pitch dan roll menggunakan Persamaan (1) dan (2) [7].

$$
\begin{aligned}
& \text { Picth }=\operatorname{artan}\left(\frac{a_{x}}{\sqrt{\left(a_{x}\right)^{2}+\left(a_{z}\right)^{2}}} x\left(\frac{180}{\pi}\right)\right. \\
& \text { Roll }=\operatorname{artan}\left(\frac{a_{x}}{\sqrt{\left(a_{y}\right)^{2}}+\left(a_{z}\right)^{2}} x\left(\frac{180}{\pi}\right)\right.
\end{aligned}
$$


Keterangan :

$$
\begin{aligned}
& \text { ax }=\text { Nilai Accelerometer } \text { pada sumbu } \mathrm{x} \\
& \text { ay }=\text { Nilai Accelerometer } \text { pada sumbu } \mathrm{y} \\
& \text { az }=\text { Nilai Accelerometer } \text { pada sumbu } \mathrm{z} \\
& \pi=\text { Phi }(3,14159)
\end{aligned}
$$

Pemasangan sensor IMU sejajar dengan Payload sehingga pemasanagn Accelero dan Gyroscope (MPU 0650) Sejajar dengan muatan roket, untuk sumbu y sejajar dengan payload dan sumbu x melintang dengan payload. Karena sensor kompas (HMC5883L) sudah termasuk bagian dari sensor IMU maka pemasangannya sejajar dengan payload dan untuk sumbu y sejajar dengan payload dan sumbu x sejajar dengan payload.

\subsection{Blok Diagram dan Perakitan Muatan Roket}

Muatan roket yang yang dibuat terdiri dari mikroprosesor Arduino nano, sensor IMU, telemetry, sistem catu daya dari baterai. Blok diagram dari rangkaian ini dapat dilihat pada Gambar 3 Perakitan IMU (Inertial Measurement unit) digunakan untuk melakukan uji fungsional sensor IMU dalam mengambil data Gyroscope. Accelerometer dan Magnetometer. IMU yang digunakan adalah IMU 10 DOF Gy-87. Data kompas juga dibutuhkan dalam penelitian ini sebagai bahan perbandingan untuk mengetahui arah muatan.

Sensor IMU memiliki 6 pin diantaranya VCC, GND, SDA, SCL, INT dan FSYNC. Dalam perakitannya, hanya ada 4 pin IMU yang digunakan. VCC disambungkan dengan data 5V arduino. Pin SDA dihubungkan dengan pin analog (A4) di arduino. Pin SCL dihubungkan dengan pin analog (A5) di Arduino. Penggunaan pin SDA dan SCL dapat dihubungkan dengan pin analog lainnya disesuaikan dengan program yang dibuat. Sensor IMU memiliki LED merah di bagian board, LED akan menyala ketika sensor telah terpasang dengan benar.
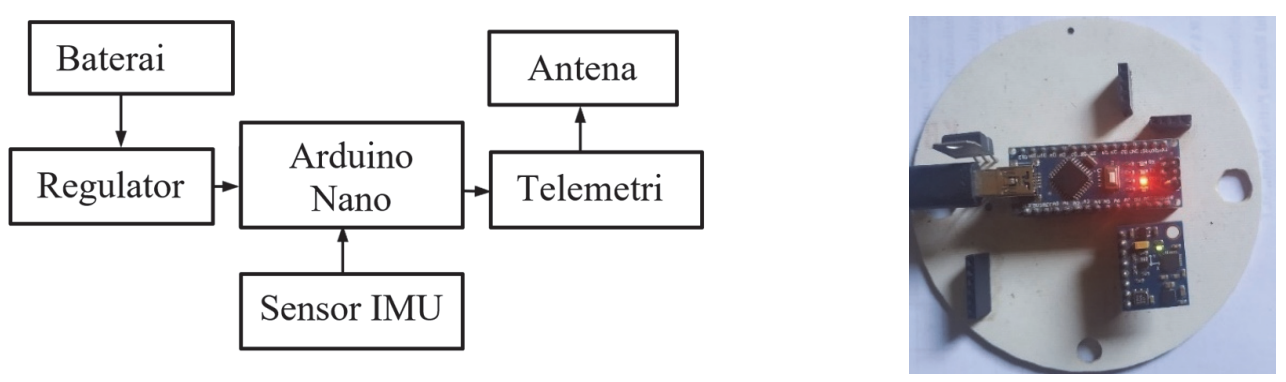

Gambar 3. Blok Diagram Sensor IMU 10 DOF

\section{HASIL DAN PEMBAHASAN}

\subsection{Pengujian Sensor}

a) Pengujian Sensor MPU6050 (Accelerometer dan Gyroscope)

Sensor MPU 6050 pada modul IMU 10 DOF yang digunakan pada Payload yang dirancang terdiri atas 2 sensor yaitu 3 Axis Accelerometer (ax, ay, az) dan 3 Axis Gyroscope $(g x, g y, g z)$. Sensor ini berfungsi memonitoring sudut dinamik roket saat diluncurkan sehingga dapat divisualisasikan pada GUI. Untuk pengiriman data sensor yang telah diolah oleh Arduino ke Ground Segmet menggunakan baudrate 57600. Pada pengujian ini dilakukan pengujian pengukuran percepatan terhadap sumbu x, sumbu y, dan sumbu z dan pengujian Gyroscope 
terhadap sumbu x, sumbu y dan sumbu z. Berikut adalah hasil pengujian sensor Accelerometer dan Gyroscope. Dari rumus 1 dan 2 maka diperoleh sudut pitch dan roll. Untuk hasil perhitungan sudut roll dan pitch berdasarkan hasil pengambilan data dari sensor acclero dan gyroscope dapat dilihat pada tabel 1. Dan untuk hasil pengambilan data raw dari sensor acclero dan gyroscope ditampilkan dalm serial monitor Arduino IDE dapat dilihat di gambar 4.

Tabel 2. Data hasil pengujian percepatan linear dan angular Muatan Roket

\begin{tabular}{|c|c|c|c|c|c|c|c|c|c|}
\hline \multirow[t]{2}{*}{ No } & \multirow{2}{*}{$\begin{array}{c}\text { Ketinggian } \\
\text { (m) }\end{array}$} & \multicolumn{3}{|c|}{$\begin{array}{l}\text { Data Sensor } \\
\text { Accelerometer }\end{array}$} & \multicolumn{3}{|c|}{$\begin{array}{c}\text { Data Sensor } \\
\text { Gyroscope }\end{array}$} & \multirow{2}{*}{$\begin{array}{c}\text { Sudut } \\
\text { Roll } \\
\left({ }^{\circ}\right)\end{array}$} & \multirow{2}{*}{$\begin{array}{c}\text { Sudut } \\
\text { Picth } \\
\left({ }^{\circ}\right)\end{array}$} \\
\hline & & $\mathbf{a x}$ & ay & $\mathbf{a z}$ & gx & gy & $\mathbf{G z}$ & & \\
\hline 1 & 1,99 & 5264 & 3452 & 15076 & -517 & 223 & 139 & 85,52 & 18,88 \\
\hline 2 & 155.16 & -2280 & -744 & 32767 & -1139 & 1878 & 18945 & $-75,88$ & $-52,4$ \\
\hline 3 & 308.74 & -316 & 296 & 32767 & -2688 & 7749 & 6458 & -28 & 27,36 \\
\hline 4 & 482.81 & 1240 & 956 & -11136 & -1481 & -458 & 0 & 81,03 & 78,3 \\
\hline 5 & 554.63 & 452 & 404 & -8340 & -842 & 94 & 13864 & 72,12 & 70,16 \\
\hline 6 & 628.2 & 800 & 480 & -5644 & -691 & 397 & 12012 & 82,9 & 78,36 \\
\hline 7 & 753.94 & 484 & 56 & -2992 & -798 & -1083 & 8397 & 83,7 & 46,99 \\
\hline 8 & 872.46 & -3656 & 5068 & 20144 & 13695 & -6964 & 32767 & $-84,41$ & 85,90 \\
\hline
\end{tabular}

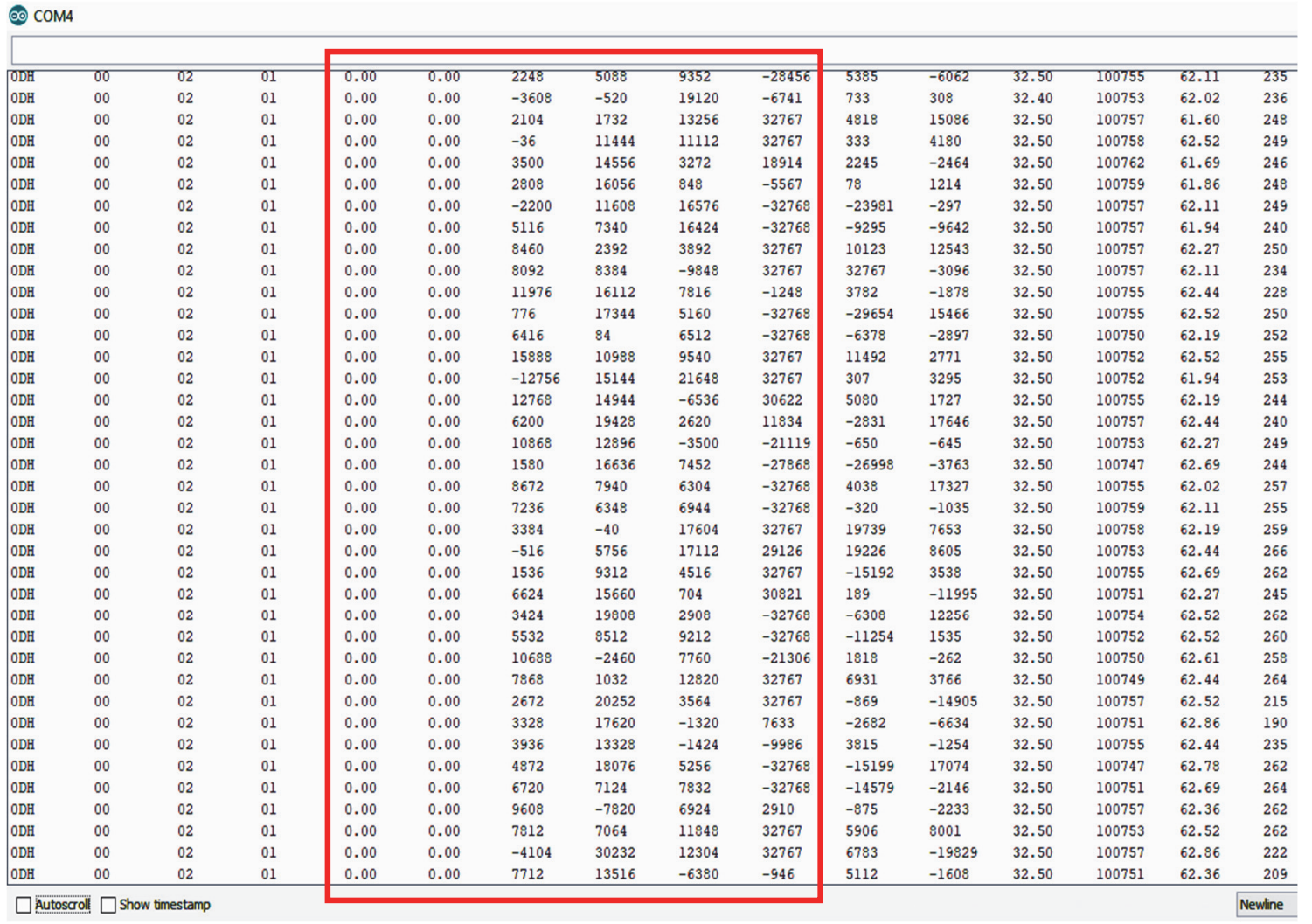

Gambar 4. Tampilan hasil pengukuran akselerasi linear dan angular 


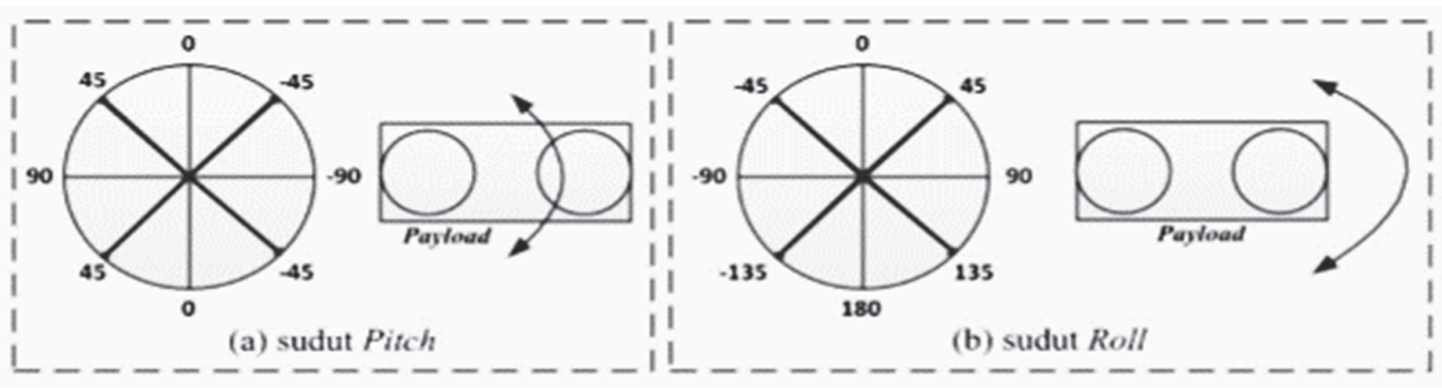

Gambar 5. Pegukuran sudut Picth dan Roll

Gambar 5 merupakan hasil pengujian untuk sensor kemiringan menggunakan 3 Axis accelerometer dimana untuk hasil pengukuran kemiringan pada sudut roll diperoleh data ketika kondisi payload miring ke kiri didapatkan data sudut kemiringan positif dengan nilai 0-180 derajat. Sedangkan ketika payload miring ke kanan diperoleh data negatif dengan nilai 0-(-180) derajat. Dari data pada Gambar 4 dapat diketahui bahwa pada saat kondisi payload normal sudut roll adalah 0 derajat. Sedangkan pada saat kondisi payload terbalik maka diperolah sudut \pm 180 derajat. Pada uji coba pengukuran nilai kemiringan terkadang pada saat kondisi payload diam data kemiringan pitch dan roll mengalami perubahan. Tetapi pada saat kondisi payload bergerak atau payload miring maka sudut yang diukur sesuai dengan sudut kemiringannya. Berdasarkan hasil pengujian untuk sensor 3 axis accelerometer maka dapat disimpulkan bahwa sensor accelerometer ini dapat berfungsi sebagai pengukur kemiringan benda dan masih memiliki noise ketika benda tersebut diam. Untuk melihat data hasil percobaan Accelero dan Gyroscope dapat dilihat pada gambar 6.
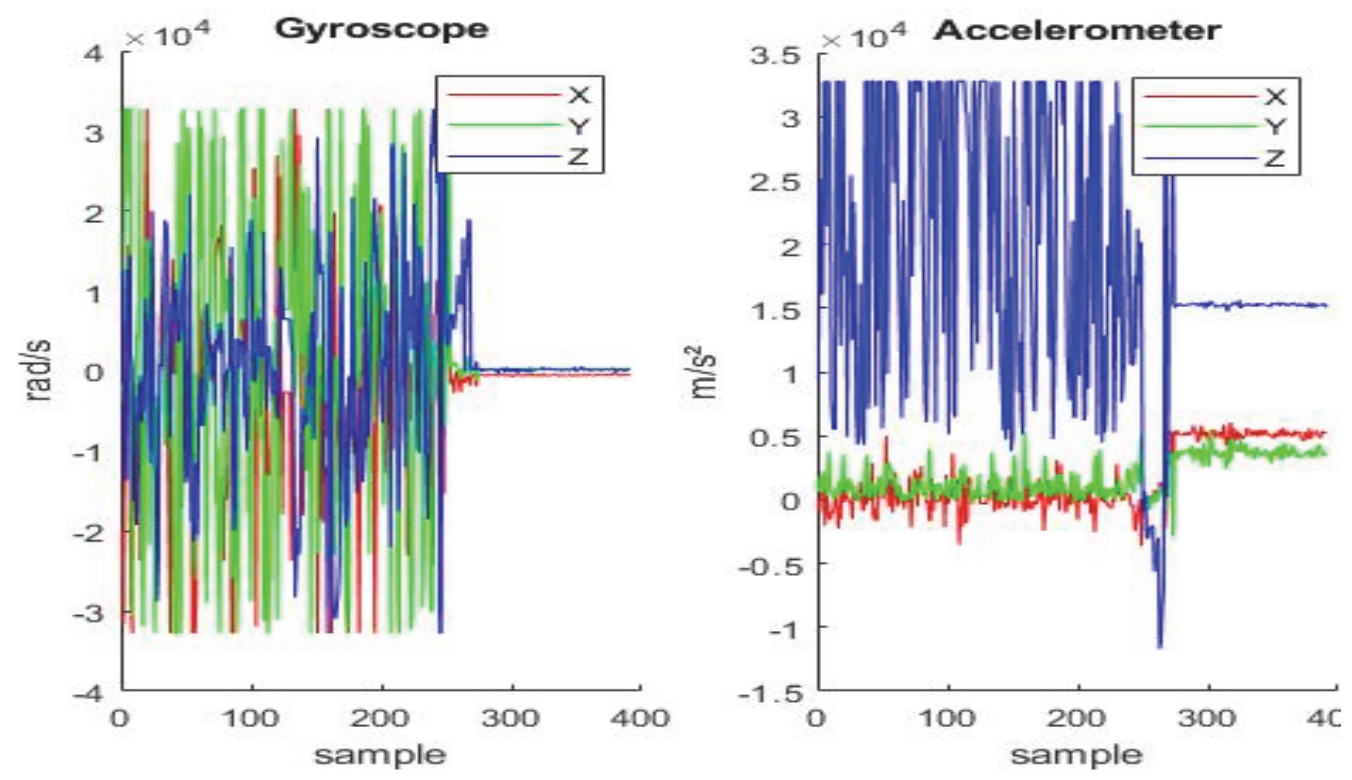

Gambar 6. Data hasil percobaan Accelerometer dan Gyroscope 
b) Pengujian Sensor Kompas

Pada pengujian ini akan dibahas tentang sensor 3 axis magnetometer HMC5883L. Sensor 3 axis magnetometer (HMC5883L) ini merupakan sensor untuk mendeteksi medan magnetik bumi. Dengan demikian sensor magnetometer ini dapat digunakan sebagai kompas digital. Kompas ini akan digunakan sebagai penunjuk arah payload saat payload diluncurkan. Pengujian dilakukan dengan memutar payload pada arah sumbu $\mathrm{z}$ dimana payload akan berputar 360 derajat terhadap arah mata angin, yaitu utara (0 derajat), timur (90 derajat), selatan (180 derajat), dan barat (270 derajat). Sensor magnetometer ini digunakan sebagai kompas digital yang berfungsi untuk mendeteksi sudut pada arah yaw. Berikut adalah hasil pengujian kompas digital ini yang ditunjukkan pada Gambar 7.

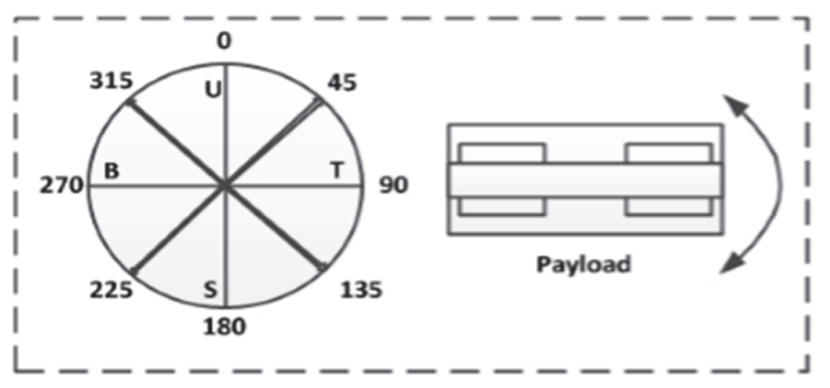

Gambar 7. Simulasi Hasil Pengujian Kompas

Tabel 3. Pengujian Kalibrasi Arah Menggunakan Sensor Kompas

\begin{tabular}{c|c|c|c|c|c|c|c}
\hline \multirow{2}{*}{ No. } & \multicolumn{2}{|c|}{$\begin{array}{c}\text { Sensor Magnetometer } \\
\text { (kompas) }\end{array}$} & $\begin{array}{c}\text { Derajat } \\
\text { (Sebenarnnya) }\end{array}$ & $\begin{array}{c}\text { Derajat } \\
\text { (Pengukuran) }\end{array}$ & $\begin{array}{c}\text { Arah Mata } \\
\text { Angin }\end{array}$ & Error (\%) \\
\cline { 2 - 7 } & $\mathbf{m}_{\mathbf{y}}$ & $\mathbf{m}_{\mathbf{x}}$ & $\mathbf{m}_{\mathbf{z}}$ & & 0.14 & Utara & \\
\hline 1 & 37 & -8.18 & 23.57 & $0 / 360$ & 45.51 & Timut Laut & 1,12 \\
\hline 2 & 8 & 5 & 30 & 45 & 90.34 & Timur & 0.37 \\
\hline 3 & 1.94 & 6.36 & 28.78 & 90 & 134.43 & Tenggara & 0.42 \\
\hline 4 & -3.18 & 5.18 & 30.71 & 135 & 181.88 & Selatan & 1.03 \\
\hline 5 & -29.55 & 5.36 & 33.47 & 180 & 227.74 & Barat Daya & 1.20 \\
\hline 6 & -30.73 & -27.45 & 23.27 & 225 & 273.41 & Barat & 1.24 \\
\hline 7 & -11.82 & -56.36 & 20.41 & 270 & 316.68 & Barat Laut & 0.53 \\
\hline 8 & 33.91 & -49.82 & 15.61 & 315 & & $\mathbf{5 . 9 1}$ \\
\hline \multicolumn{7}{|c|}{}
\end{tabular}

Rumus menghitung Persentase error pada uji arah kompas mengikuti Persamaan (3)

$$
\frac{\text { Data Sensor Kompas-Nilai Sebenarnya }}{\text { Data Sensor kompas }} \times 100 \%
$$

Pengujian kalibrasi arah angin menggunakan sensor kompas yang terdapat pada Sensor IMU 10 DOF. Skenario pengujian yang dilakukan dengan memutar sensor kompas sesuai dengan arah mata angin secara manual di atas kertas dengan memberi tanda utara, timur, selatan dan barat. Pengujian ini dilakukan untuk melihat perbandingan derajat untuk 
menentukan arah mata angin. Berdasarkan data pengujian Tabel 2, data derajat yang dihasilkan dari pengukuran antara sensor dan derajat sebenarnya terdapat sedikit error.

\subsection{Uji Fungsional}

\section{a) Uji G Force}

Pengujian G-Force dilakuan untuk mengetahui apakah sistem telemetry masih dapat bekerja denagn baik mengirimkan data ke GCS apabila Payload diputar putar 360 derajat dengan cepat. Pengujian payload menggunakan FPGA (Field Progamable Gate Array). Pengujian ini dilakukan dengan memberikan gaya g sebesar $6 \mathrm{~g}$ terhadap muatan roket. Sinyal yang diproses FPGA adalah sinyal PWM yang diberikan ke driver motor untuk mengatur kecepatan putar alat agar alat memiliki gaya sentrifugal. Data pengujian ditampilkan pada grafik seperti Gambar 8.

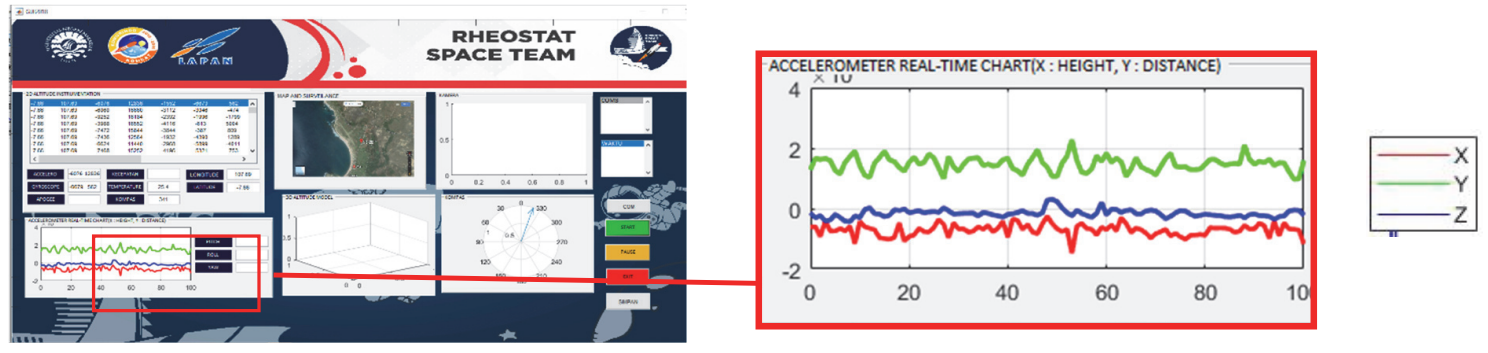

Gambar 8. Grafik Uji coba G-Force

Dari hasil pengujian yang dilakukan di Balai Uji Teknologi Roket LAPAN, data Acceleromter mengalami perubahan sehingga grafik yang ditampilkan mengalami perubahan yang signifikan.

b) Uji G-Shock

Pengujian G-Shock berfungsi untuk mengetahui apakah sistem telemetry masih dapat bekerja dengan baik apabila Payload diberi hentakan. Jika pada saat diberi hentakan, payload masih dapat mengirimkan data ke GCS, berarti pengujian G-Shock berhasil dilakukan, pengujian ini dilakukan di Balai Uji Teknologi Roket LAPAN Garut. Berikut grafik data hasil pengujiaqn $G$-Shock yang ditunjukan pada Gambar 10.

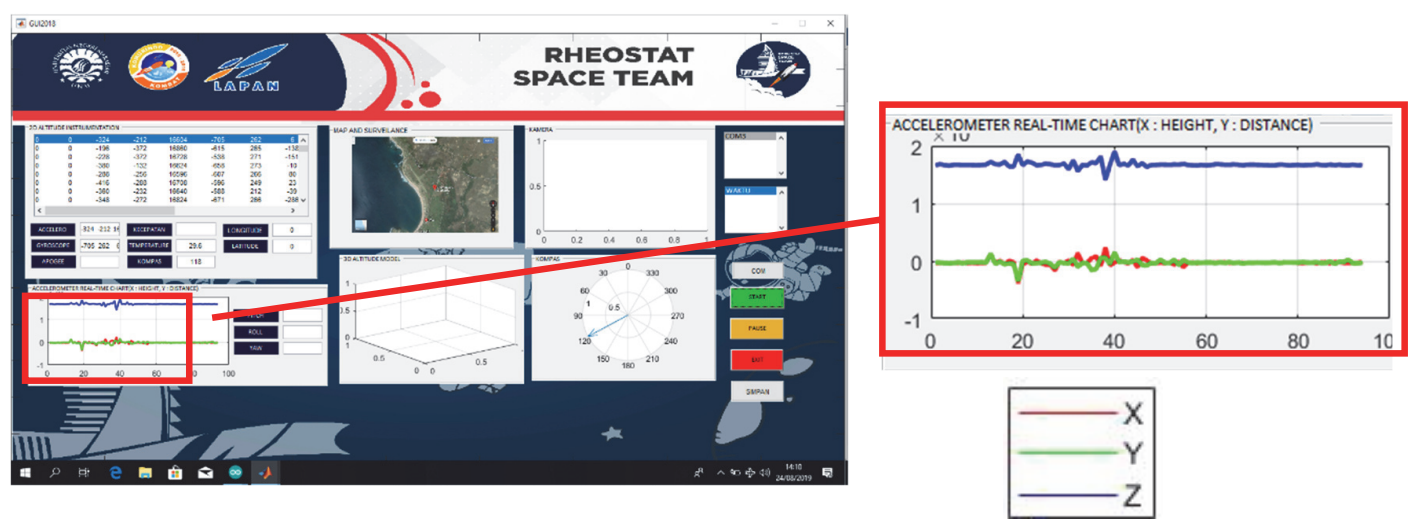

Gambar 10. Grafik Uji Coba G-Shock 
Dari hasil pengujian, didapat data Accelerometer perubahan nilai yang besar pada Axis $\mathrm{z}$ dibandingkan nilai axis x dan y. Hal ini dikarenakan pada saat dilakukan pengujian G-Shock, payload dihentakkan dari sisi atas ke bawah yang mengakibatkan terjadinya perubahan nilai akselerasi pada axis $\mathrm{z}$.

\section{c) Pengujian Vibrasi}

Pengujian Vibrasi adalah pengujian yang dilakukan dengan cara memberikan goncangan pada Payload. Tujuannya untuk mengetahui apakah semua komponen pada pada Payload dapat berfungsi dengan baik mengirimkan data sensor ke GCS. Data hasil pengujian vibrasi dapat dilihat pada Gambar 12.

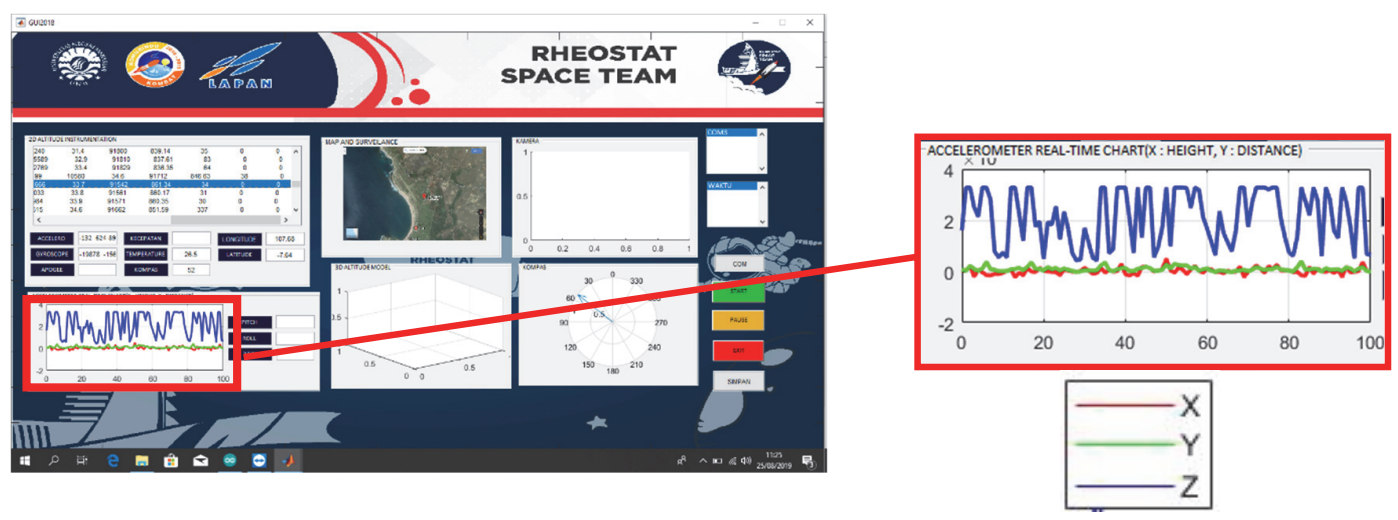

Gambar 12. Grafik Uji Vibrasi

Dari hasil pengujian yang dilakukan data accelerometer menunjukan perubahan di semua sumbu. Ini dikarenakan pada saat pengujian payload, sistem digoyangkan atau diberi getaran yang mengakibatakan perubahan nilai di semua axis accelerometer.

\section{KESIMPULAN}

Dari hasil penelitian yang telah dikerjakan, penulis memberikan beberapa kesimpulan sebagai berikut:

1. Rancang Bangun implementasi sensor Inertial meansuremennt unit (IMU) untuk monitoring Getaran Pada Payload (Muatan Roket) tersebut menggunakan IMU 10 DOF (GY-87) terdiri dari Acceleromoter. Gyroscope, Magnetometer (kompas) dan Barometer. Sensor ini dapat mendeteksi setiap perubahan sudut yang dialami oleh payload saat meluncur sehingga memudahkan untuk mendeteksi getarannya.

2. Berdasarkan hasil pengujian G-Shock, G-Foce dan Vibrasi menunjukkan bahwa payload dapat bekerja dengan baik. Sesuai dengan hasil pembacaan data pada Graphical user Interface (GUI) dapat ditampilkan dan menunjukkan muatan roket bekerja dengan baik, untuk pengiriman data dari payload ke Ground Segment menggunakan badrate 57600 .

3. Pada pengujian ini terdapat error pada sensor Inertial Meansurement unit (IMU) yang menggunakan jenis sensor IMU 10 DOF. Error yang didapatakan yaitu pada saat pengujian arah kompas yang nilai rata-ratanya sebesar $5,1 \%$ 


\section{Daftar Pustaka}

[1] Markgraf, M., Montenbruck, O., Hassenpflug, F., Turner, P., Bull, B., \& Bauer, F. (2001). A low cost GPS system for real-time tracking of sounding rockets.

[2] Bull, B., Diehl, J., Montenbruck, O., Markgraf, M., \& Bauer, F. (2002). Flight Performance Evaluation of Three GPS Receivers for Sounding Rocket Tracking.

[3] Hammerschmidt, D. (2011). U.S. Patent No. 7,950,281. Washington, DC: U.S. Patent and Trademark Office.

[4] Albéri, M., Baldoncini, M., Bottardi, C., Chiarelli, E., Fiorentini, G., Raptis, K. G. C., ... \& Strati, V. (2017). Accuracy of flight altitude measured with low-cost GNSS, radar and barometer sensors: Implications for airborne radiometric surveys. Sensors, 17(8), 1889.

[5] Buku Panduan KOMURINDO-KOMBAT Tahun 2018-2019. (2019). Pusat Sains dan Teknologi Atmosfer Lembaga Penerbangan dan Antariksa Nasional (LAPAN). Diakses dari website: www.komurindo-kombat.lapan.go.id

[6] Suditano, Soeparto, et. al. (2011). Prototype Payload Untuk Uji Muatan Roket. Electrical Enginnering Journal. 2 (1). pp. 66-80

[7] Wijaya, et al. (2014). Perancangan Muatan Roket Sebagai Sistem Monitoring Cuaca Berbasis Mikrokontroler dan Visual C\#. Universitas Jember

[8] Riyadi, Muhammad. (2009). Pendeteksi Posisi Menggunakan Sensor Accelerometer MMA7260Q Berbasis Mikrokontroler ATMEGA 32. Universitas Diponegoro. Diakses dari website: www.researchgate.net/publication/279425581 tanggal 13 Juni 2019) 